\title{
22. Sapphirine from Metamorphosed Layered Complex of Mt. Poroshiri, Hidaka Metamorphic Belt, Hokkaido
}

\author{
By Sumio Mryashita,*) Masayuki Komatsu,**) \\ and Seiji HashIMoTo*) \\ (Communicated by Takeo Watanabe, M. J. A., March 12, 1980)
}

Introduction. Although sapphirine is not uncommon constituent of high grade silica poor and high alumina metamorphic rocks, no occurrence has been reported in Japan despite the presence of higher grade metamorphic rocks formed under the physical condition allowing the formation of sapphirine. However, the authors have realized the first occurrence in Japan during the survey of metamorphic rocks in the Hidaka metamorphic belt occupying the axial part of Hokkaido extended for about $150 \mathrm{~km}$ in the N-S direction. The sapphirinebearing rock is found in metamorphosed troctolite belonging to the Mt. Poroshiri layered gabbroic complex included in the Western zone of metamorphic belt (Hashimoto, 1975).

Here the preliminary report on the chemical and optical properties of sapphirine is made with brief description on mode of occurrence.

Geological setting. Mt. Poroshiri is situated in the northern part of the Hidaka Mountains. The Mt. Poroshiri layered complex comprises three stratified zones according to the original lithology (Miyashita and Maeda, 1978), though massive metamorphic rocks with various degrees of recrystallization occur very irregularly. The lower zone of the complex given in Fig. 1 was originally composed of anorthosite, troctolite, wehrlite and dunite. Fine rhythmic layering is well developed in these rocks (Miyashita and Hashimoto, 1975). The middle zone of the complex consists of olivine gabbro with faint layering, and the upper zone is composed of massive gabbro. Two steps of metamorphism are distinguished in the Mt. Poroshiri complex. The earlier metamorphism was of retrogressive nature and occurred under a static condition. It yielded sapphirine in an altered anorthositic troctolite belonging to the lower zone of the complex. The second step occurred dynamically due to uplift of the Western zone (Grapes et al., 1977).

Mode of occurrence. The sapphirine-bearing rock found from

*) Department of Geology and Mineralogy, Faculty of Science, Hokkaido University, Sapporo, Japan.

**) Department of Geology and Mineralogy, Faculty of Science, Niigata University, Niigata, Japan. 


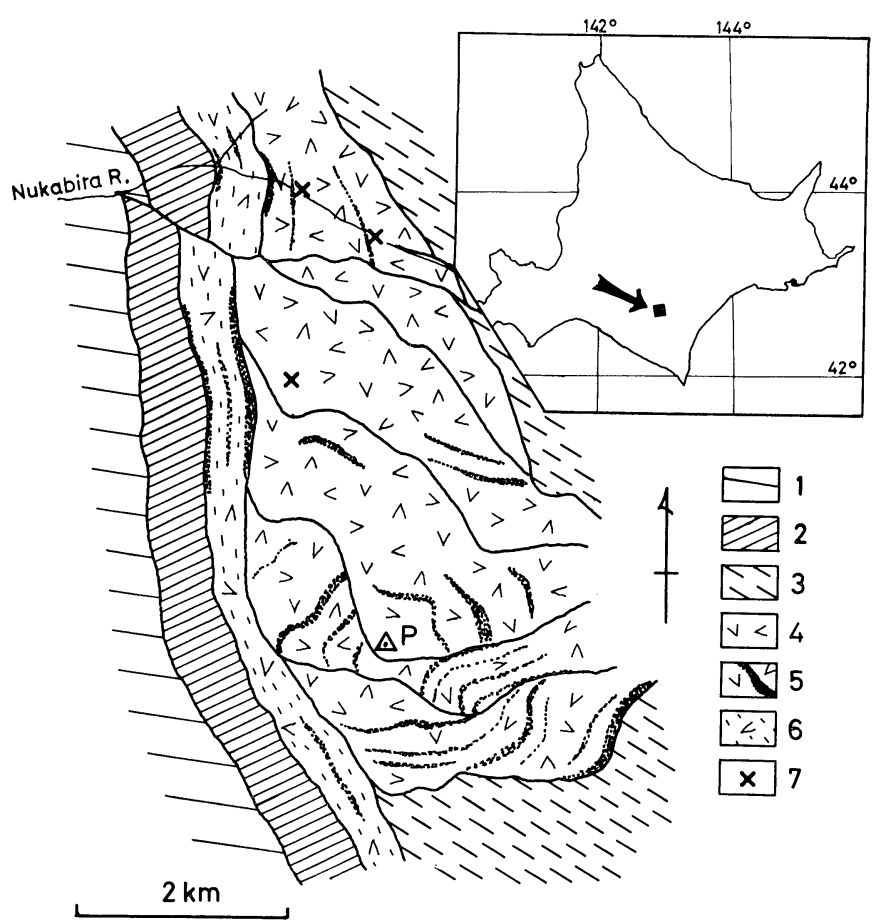

Fig. 1. Simplified geologic map of Mt. Poroshiri area. 1: Hidaka Super Group. 2: Greenschist and Epidote amphibolite. 3: Green-hornblende amphibolite and Plagioclase blastoporphyritic amphibolite. 4: Plagioclase-olivine cumulate (Troctolite) and its metamorphosed equivalent. 5: Olivine cumulate and its metamorphosed rock. 6: Mylonite. 7: Locality of sapphirine. $\mathrm{P}$ is the top of Mt. Poroshiri.

three outcrops (Fig. 1) is composed of hornblende with subordinate amounts of sapphirine and plagioclase. Corundum, spinel, gedrite, chlorite and clinozoisite occur as accessories. The sapphirine-bearing rock has a hetrogeneous texture (Fig. 2), which is probably due to its original igneous texture. Small domains consisting of mosaic hornblende are enclosed within a cluster of very fine hornblende and sapphirine. Anhedral plagioclase (An 85-95) occur in the latter. Both hornblendes are colorless to pale green under the microscope and have a pargasitic composition. Corundum generally occurs as scattered pod up to $10 \mathrm{~mm}$, but rarely occurs in vein together with spinel and chlorite.

As shown in Table I, bulk compositions of the sapphirine-bearing rock and unmetamorphosed troctolite are almost the same. The compositional similarity and textural characteristic suggest that the sapphirine-bearing rock is derived from troctolite.

Sapphirine. $\left(\mathrm{Mg}, \mathrm{Fe}^{2+}, \mathrm{Fe}^{3+}, \mathrm{Al}\right)_{8} \mathrm{O}_{2}\left[(\mathrm{Al}, \mathrm{Si})_{6} \mathrm{O}_{18}\right]$. The sapphirine is fine-grained, 0.5 to $0.02 \mathrm{~mm}$ in diameter, and is colorless to light blue under the microscope. Pleochroism is very weak. Optical 
properties of the sapphirine are tabulated in Table II. The $2 \mathrm{~V}_{\mathrm{x}}$ of observed sapphirines ranges from $55^{\circ}$ to $65^{\circ}$. X-ray diffraction data are given in Table III.

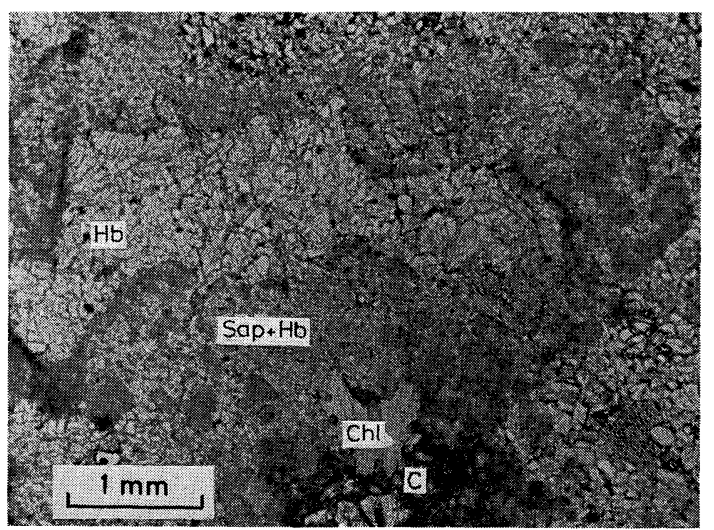

Fig. 2. Texture of sapphirine-bearing rock. Hb: Hornblende. Sap $+\mathrm{Hb}$ : Sapphirine and hornblende. Chl: Chlorite. C: Corundum.

Table I. Bulk compositions of troctolite and sapphirine-bearing rock

\begin{tabular}{lrr|rrr} 
& \multicolumn{1}{c}{1} & \multicolumn{1}{c}{2} & & \multicolumn{1}{c}{1} & \multicolumn{1}{c}{2} \\
\hline $\mathrm{SiO}_{2}$ & 44.23 & 43.28 & $\mathrm{CaO}$ & 11.32 & 10.00 \\
$\mathrm{TiO}_{2}$ & .08 & .07 & $\mathrm{Na}_{2} \mathrm{O}$ & 1.62 & 1.14 \\
$\mathrm{Al}_{2} \mathrm{O}_{3}$ & 22.66 & 22.75 & $\mathrm{~K}_{2} \mathrm{O}$ & .01 & .14 \\
$\mathrm{Fe}_{2} \mathrm{O}_{3}$ & .67 & .90 & $\mathrm{P}_{2} \mathrm{O}_{5}$ & .04 & .09 \\
$\mathrm{FeO}$ & 4.09 & 3.58 & $\mathrm{H}_{2} \mathrm{O}( \pm)$ & 1.08 & 1.29 \\
$\mathrm{MnO}$ & .06 & .09 & & & 100.11 \\
$\mathrm{MgO}$ & 14.15 & 15.37 & Total & 99.00 \\
\hline
\end{tabular}

1: Sample no. KK2-3, troctolite; plagioclase 65, olivine 35\%. 2: Sample no. Sf-1, Sapphirine-bearing rock; hornblende 83, plagioclase 3, sapphirine 9 , corundum 3 , spinel 1 , chlorite $1 \%$.

Table II. Optical properties of sapphirine

\begin{tabular}{llll}
\hline$\alpha$ & 1.711 & Twinning & Penetration twin \\
$\beta$ & 1.713 & Color & Light blue \\
$\gamma$ & 1.717 & Pleochroism & Very weak, \\
$\partial$ & 0.006 & & $\alpha:$ Colorless \\
$2 \mathrm{~V} \alpha$ & $55^{\circ}-65^{\circ}$ & & $\beta:$ Colorless \\
$\beta=\mathrm{y}:$ O.A.P. $(010)$ & & $\gamma:$ Pale blue \\
\hline
\end{tabular}

Three types of sapphirine are distinguished in terms of its form; very irregular anhedral crystal, prismatic crystal with numerous inclusions of hornblende and prismatic crystal free from inclusion. It may be worth nothing that cruciform twin is observed in the sapphirine of the prismatic crystal containing inclusion as shown in Fig. 3, since 
polysynthetic twin has been reported from many localities (e.g., Lensch, 1971) but the occurrence of penetration twin is very rare. Herd et al. (1969) stated presence of penetration twin in sapphirine, however detailed description on the twin has not been done. A preliminary study with the universal stage shows that the crossing angle between the symmetrical plane and $(010)$ of each individual is about $60^{\circ}$.

Table III. X-ray powder data for sapphirine

\begin{tabular}{|c|c|c|c|c|c|c|c|}
\hline \multicolumn{2}{|c|}{ Poroshiri } & \multicolumn{2}{|c|}{ Fiskenaesset } & \multicolumn{2}{|c|}{ Poroshiri } & \multicolumn{2}{|c|}{ Fiskenaesset } \\
\hline $\mathrm{d} . \AA$ & $\mathrm{I} / \mathrm{I}_{1}$ & d. Å & $\mathrm{I} / \mathrm{I}_{1}$ & d. Å & $\mathbf{I} / \mathrm{I}_{1}$ & d. A & $\mathrm{I} / \mathrm{I}_{1}$ \\
\hline \multirow[t]{2}{*}{3.61} & 15 & 3.600 & 10 & 2.13 & 20 & 2.127 & 12 \\
\hline & & 3.361 & 20 & & & 2.072 & 11 \\
\hline 3.28 & 15 & 3.277 & 10 & 2.03 & 45 & 2.023 & 60 \\
\hline 3.00 & 70 & 2.990 & 65 & 2.02 & 60 & 2.015 & 90 \\
\hline 2.85 & 40 & 2.844 & 50 & & & 1.5517 & 10 \\
\hline 2.78 & 20 & 2.762 & 25 & 1.544 & 25 & 1.5403 & 25 \\
\hline \multirow[t]{2}{*}{2.70} & 15 & 2.695 & 10 & 1.439 & 50 & 1.4401 & 30 \\
\hline & & 2.647 & 10 & 1.423 & 50 & 1.4353 & 65 \\
\hline 2.58 & 30 & 2.576 & 30 & 1.412 & 25 & 1. 4192 & 65 \\
\hline 2.45 & 100 & 2.447 & 100 & & & 1.4073 & 30 \\
\hline 2.36 & 30 & 2.347 & 35 & & & & \\
\hline
\end{tabular}

Fiskenaesset: Moore (1969).

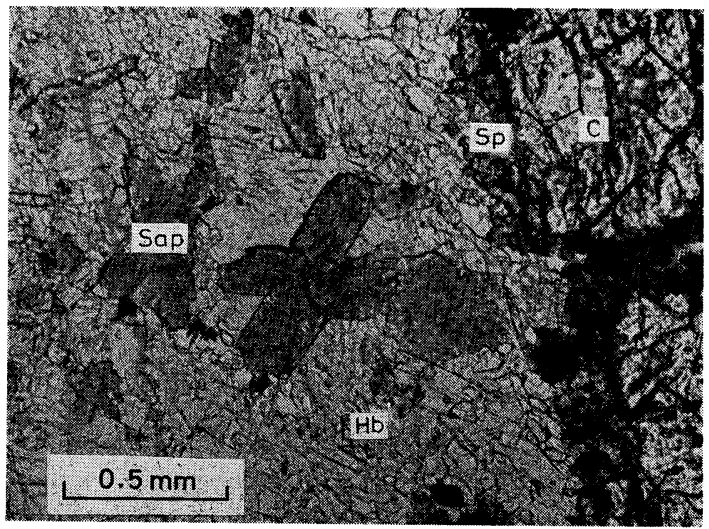

Fig. 3. Cruciform twin of sapphirine. Hb: Hornblende. Sap: Sapphirine.

C: Corundum. Sp: Spinel. Sapphirine contains numerons inclusions.

Selected microprobe analyses of anhedral and prismatic sapphirine free from inclusion are shown in Table IV. $\mathrm{SiO}_{2}$ and $\mathrm{Al}_{2} \mathrm{O}_{3}$ contents of the sapphirines range from about 11 to $14 \mathrm{wt} \%$ and from 66 to 62 wt $\%$, indicating $\mathrm{MgSi} \rightleftarrows \mathrm{AlAl}$ substitution. Vogt (1947) had suggested a general formula for sapphirine as $\mathrm{Mg}_{16-n} \mathrm{Al}_{32+2 n} \mathrm{Si}_{8-n} \mathrm{O}_{80}$ with $n$ vary- 
ing from 0 to about 2.5. Recently many analyses of sapphirine have been published and confirmed the formula by Vogt (1947). The minimum $n$ value $(n=0)$ is given by Segnit (1957) and the maximum value $(n=2.8)$ is reported by Cameron (1976). The $n$ value of the Poroshiri sapphirine ranges from 1.20 to 2.70 and those poor in $\mathrm{SiO}_{2}$ of the Poroshiri sapphirine have close value to the maximum value. It is interesting that prismatic sapphirine free from inclusion is rich in $\mathrm{SiO}_{2}$, on the other hand anhedral sapphirine and prismatic sapphirine with inclusion have more aluminous composition.

Table IV. Selected analyses of sapphirine

\begin{tabular}{lrr||lrr}
\hline & \multicolumn{1}{c||}{1} & \multicolumn{1}{c|}{2} & \multicolumn{3}{c}{ Numbers of cations; $\mathrm{O}=20$} \\
\hline $\mathrm{SiO}_{2}$ & 13.28 & 11.53 & $\mathrm{Si}$ & 1.573 & 1.363 \\
$\mathrm{Al}_{2} \mathrm{O}_{3}$ & 62.92 & 66.02 & $\mathrm{Al}$ & 8.783 & 9.196 \\
$\mathrm{Cr}_{2} \mathrm{O}_{3}$ & n.d. & .13 & $\mathrm{Cr}$ & n.d. & .012 \\
$\mathrm{FeO}$ & 3.95 & 3.79 & $\mathrm{Fe}^{2+}$ & .391 & .375 \\
$\mathrm{MgO}$ & 18.61 & 17.50 & $\mathrm{Mg}$ & 3.286 & 3.083 \\
$\mathrm{CaO}$ & .02 & .03 & $\mathrm{Ca}$ & .003 & .004 \\
\hline Total & 98.78 & 99.00 & Total & 14.036 & 14.033 \\
\hline
\end{tabular}

* Total Fe as FeO. 1: Prismatic sapphirine free from inclusion, sample PU-7. 2: Anhedral sapphirine, sample 2U-8. Analysis has been made at $15 \mathrm{kV}$ accelerating potential and $0.03 \mu \mathrm{A}$ specimen current using JXA-5A electron microprobe. The corrections were made by the method of Bence and Albee (1968).

Discussion. Sapphirine is an important mineral indicating highgrade metamorphism from the granulite to the upper amphibolite facies (Turner, 1968). The occurrence of sapphirine is rare because it usually appears in the rocks with unusual chemical composition. In general, sapphirine-bearing rocks are rich in $\mathrm{Al}_{2} \mathrm{O}_{3}, \mathrm{MgO}$, and poor in $\mathrm{SiO}_{2}$ and $\mathrm{FeO}$ (Deer et al., 1978). In many sapphirine localities, metasomatism (e.g., Herd et al., 1969) or partial melting (e.g., Clifford et al., 1975) has been assumed for the production of such unusual bulk composition. However, the sapphirine-bearing rock in the present study is considered to be derived from anorthositic troctolite through the isochemical reaction introduced by an influx of water. The influx of water from the exterior has an important role for the reaction of olivine and plagiocalse leading the formation of sapphirine and hornblende.

Sapphirine-bearing rocks with the same mineral assemblage as those of the Poroshiri complex have been reported from several localities, and their metamorphic conditions have been deduced to be of the low granulite or the high amphibolite facies (e.g., Forestier and 
Lasnier, 1969). Therefore, it is considered that the lower part of the Mt. Poroshiri complex suffered from metamorphism of the same conditions.

Acknowledgments. The authors wish to express our sincere thanks to Dr. Takeo Watanabe, M. J. A., Drs. Akira Kato, Teruo Watanabe, Yoshihide Ohta, Yoshiaki Yamaguchi, Soeng Gi Hoe for their kind advices. We express our deep appreciation to the members of the geological club of "Syumanokai" for the support in field survey.

\section{References}

Bence, A. E., and Albee, A. L. (1968) : J. Geol., 76, 382-403.

Cameron, W. E. (1976) : Geol. Mag., 113, 497-514.

Clifford, T. N., Stumpfl, E. F., and McIver, J. R. (1975) : Min. Mag., 40, 347-356.

Deer, W. A., Howie, R. A., and Zussman, J. (1978) : Rock-Forming Minerals, 2A, Single-Chain Silicates. Longman Group Ltd., London, 668 p.

Forestier, F. H., and Lasnier, B. (1969) : Contr. Mineral. Petrol., 23, 194-235.

Grapes, R. H., Hashimoto, S., and Miyashita, S. (1977) : J. Petrol., 18, 285-318.

Hashimoto, S. (1975) : J. Fac. Sci. Hokkaido Univ., Ser. IV, 16, 367-420.

Herd, R. K., Windley, B. F., and Chisler, M. (1969): Rapp. Grønlands Geol. Unders., 24, 1-44.

Lensch, G. (1971) : Contr. Mineral. Petrol., 31, 145-153.

Miyashita, S., and Hashimoto, S. (1975) : J. Fac. Sci. Hokkaido Univ., Ser. IX, 16, 421-452.

Miyashita, S., and Maeda, J. (1978) : Assoc. Geol. Collabor. Japan, Monograph, 21, 43-60 (in Japanese with English abstract).

Moore, P. B. (1969) : Amer. Min., 54, 31-49.

Segnit, E. R. (1957) : Min. Mag., 31, 690-697.

Turner, F. J. (1968) : Metamorphic Petrology. McGraw-Hill Book Co., New York. Vogt, Th. (1947) : Bull. Comm. géol. Finlande, 140, 15-23. 